\title{
くりさろびん中毒二因ル家兔肝臟 變化二就テ
}

京都帝國大學醫學部病理學教室

櫻 井 喜 吉

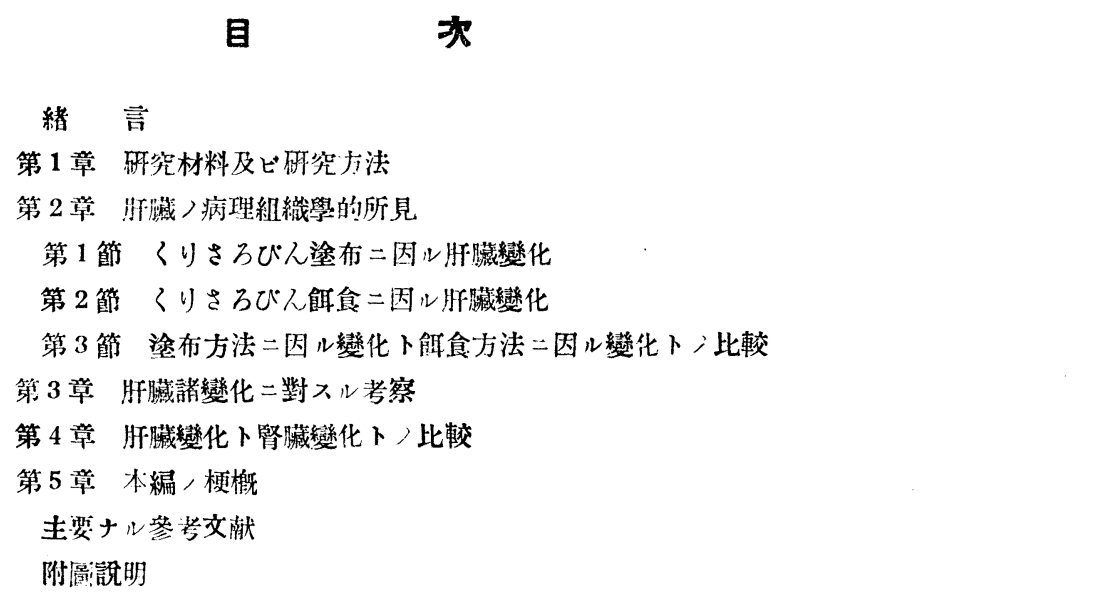

緒言

くりさろびんノ腎贜刺㦸二關シテハ，之二諭及七ル學者决シテ尠キニ非ラズ 余モ亦暴二之ガ精細ナル研究 關スル實驗的研究ナル題下二之ヨ報告スル所アリタリ，然レドモくりさろびん

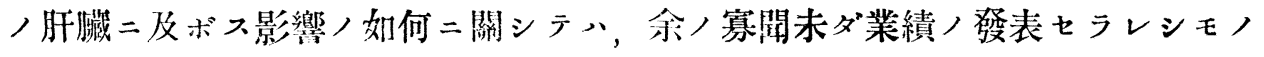
アルフ聞.カズ.

抑モ吸收セラレタルくりさろびんハ，ソノ䬣食为法二依りシ㷪合ニハ一度、 必ズ肝臟內 7 通過シ，或ハ又狳布方法二由リシ時モ血液中二吸收セラレテ其一

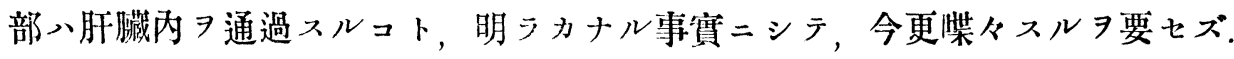
此故ニソレガ肝臟二影響 トアルナラント考フルハ寧口當然ノ事ナリ，然ルニ之二關スル文献ヨ見出シ得 ザル所以ノモノ八，〈りさろびん二因りう著起七ラル、肝臟變化 メ得ザルカ或ハ不注意二看過セラレ，為メ二先淮諸家，是レ二注月スルモノ無 
カリシニ由ルモノナルベシ．故ニ余ガ今荻二，〈りさろびん中毒二因ル家鬼肝 臟ノ變化二就キテ記述シ，以テ世人ノ注意 義ノ業ニ非ラザルぶシ.

\section{第 1 章研究材料及七研究方法}

研究材料及ビ研究方法ノ詳細ニ關シテハ, 腎臟ノ變化 之ヨ記述セルヨ以テ，此處ニハ之ヨ省略スベシ（拙者くりさろびんノ腎臟二及 ボス影響二關スル實驗的研究．日本微生物學會雜誌第 22 卷第5號）

\section{第 2 章 肝臟ノ病理組織學的所見}

\section{第 1 節 くりさろびん㳊布二因ル肝臟紸化}

1 血管撗張及ビ充盈

之ハ重要ナル所見ニシテ，甚ダ屡か認メラル、戀化ナリ，中心靜脈ハー般二 撗張シテ血液ノ充盈セルタ認ム。門脈枝ニモ亦之ヨ認ムレド, 中心静脈二比シ 程度稍低シ。肝動脈枝ノ著シク撗張セルモノ八殆ンド認メラレズ. 小葉內毛細 血管亦顯著ナル擴張及ビ充盈ヨ示ス。此毛細血管充血ハ，或ハ主トシテ小葉中 心部二，又或八専ラ小葉周邊部二著明ニシテ，其部位一定セズ，ソノ著シク高 度ナルモノニアリテハ, 小葉ノ全部二亘タリテ認メラル

血管腔內ニハ赤血球ノ充テルモノ八存スル他，血球 メテ僅カニ之 、モノアリ，纎維素ノ㭛出セルモノ、殆ンド認メラレズ.

血管內二於テ血栓, 形成七ラレタルモノヨ認メズ.

斯カル血管，著明ナル撗張二因り肝細胞，壓迫 7 蒙り，第メニソノ容積减少 シ萎縮ノ狀 7 呈センモノョ見ズ. 後二記述スルガ如ク, 肝細胞ハ却テ腫脹セリ. 格子狀緎維ハ血管，顯著ナル擴張並二充盈 $ヨ$ 示七ル部位二於テハ退行變性 示セり.

$$
2 \text { 出 血 }
$$

出血モ亦認メラル，サレド其殆ンド總テハ毛細管出血ニシテ，阴胍枝或ハ肝 動脈枝二出血 $\ni$ 起セルモノヨ觀ズ. 中心静脈二於テハ, 赤血球ノ三三個或八數 
個血管外二沉逸七ルモノアルラ僅二認メタリ，出血䇫境界ハ明ラカナルモ， アリ，又稍游暮性:二テ境界ノ明暸ナラザルモノアリ，ソノ形狀不規則ニシテー 定七ズ，大サモ種タナレドモ一般二甚ダ小ニシテ，一小葉全部二亘レルガ如キ 大ナル出血ヨ觀ルコトナク, 唯毛細管，周圍二赤血球，多數二浴出七ル程度，

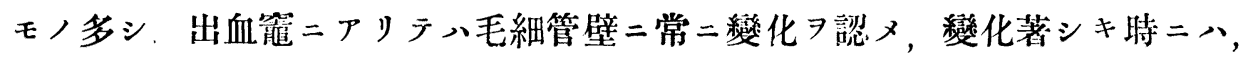
ソノ形䯚习留ムルニ過ギザルモノアリ，或ハ又殆ンド之ヨ認メザルモノアリ．

出血䇫二血色素ノ沈着习認メタルモノ無シ.

出血ノ形式ハ殆ンド腹出性出血二屬シ，血管壁ノ强キ援張二基ヶル各細胞問 隙八䔣加，壁成分，壓迫並二毒作用二因儿㘘性等相倚り亏，壁，血液成分，滲

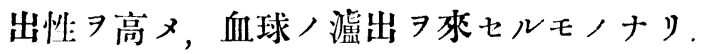

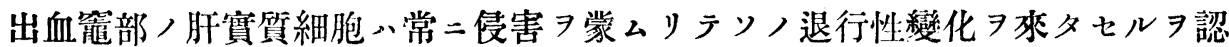
ムルモノニシテ，核及ビ原形質ノ染色性叒常ナラズ．其部二於テハ格子狀繊維 モ亦侵サレ，退行性變化 ヨ起シ，ソノ部八崩壞消失セリ。

\section{: 溷 濁 腫 脹}

之、甚名屡《認メラル、變化ニシテ重要ナル所見ナリ，其程度ノ比較的弱キ モノ八稍濔暮性二認メラレ，可ナリ高度ノモノ八，著明・ル毛細血管充盈部位 二一致シテ存ス，此變化 顆䊀狀トナレリ。核ノソレニ蕉ハレテ不明トナリ，或ハ核ノ膨大七ルモノモ認 メラル

\section{4 脂 肪 變 性}

之モ可ナリ屡く認メラル，肝細胞、腫脹シテ容積大トナリ，原形質內二八極

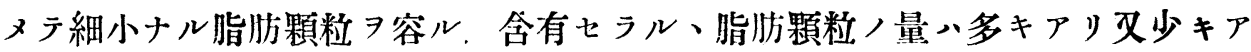
リテー一定七ズ，サレド細胞內脂坊顆粒 ヨ以テ充滿七ルガ如キ高度ノモノ八認メ

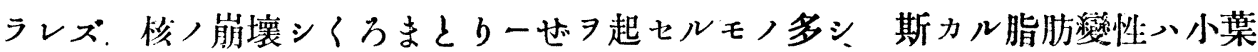
八中心部二存スルコトアリ，又其周邊部二存スルコトアリ，又小葉ノ殆ンド全 部ニ亘レルモノモアリラ，其部位－一定七ズ．然レドモ之八常二肝細胞ノ腫脹並 二顆䊀性變性ノ高度ナル部分二認メラル。

叙上ノ如ク，細胞內二現ハル、脂肪顆粒八常二極メラ細小ニシラ，可ナリ大 ナル脂肪滴ヨ容ル、コト無シ. 又其細胞二八常二退行性變化 7 認ムルモノニシ 
テ，細胞ノ健常ナルモノヨ觀ズ，郎チ余く例二於認メタルモノ八，總示脂肪 變性ニシテ，脂肪浸潤卜稱スベキモノラ觀ズ.

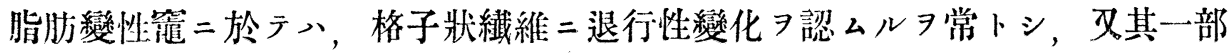
八崩壞沙失七り。

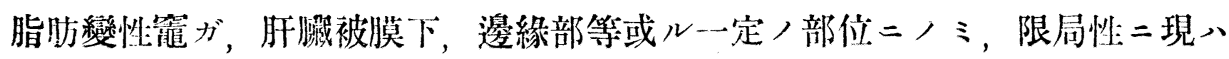
ル、ガ如キコト無シ

$$
5 \text { 境 死 }
$$

是屡ハ認メラル、重要ナル所見ナリ，大サ八種トニシテ，一小葉ノ一局部ノ

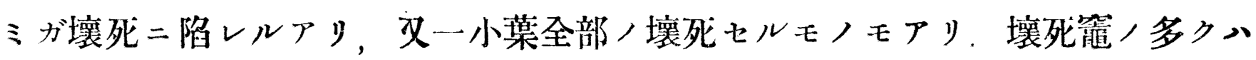
表在性ニシテ，被膜，下部二存在シ，深部ニ之ヨ認ムルェト少シ，又第29號動

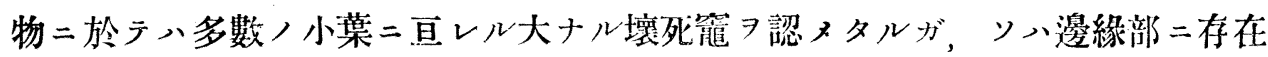
七リ.

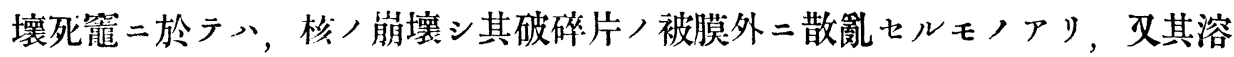
解消失七ルモノアリ。核ノぴくの一ぜ陷レルモノ八比較的少ク，腔泡形成 認ムルモノ無シ。原形質八無構造トナリ活穢二染着ス，斯カル壤死筐二於テ， 其構造ノ全ク不明トナレルモノアリ，又省ホ細胞ノ形骹习存セルモノモ認メラ ル.

多ク八壤死筐二於テハ，其部二脂肪顆粒，存在 7 認又得ルモノニシテ，其小 ナル病筐ニアリテッずだん正染色標本二於テ，肝細胞ノ形狀 ナシテ集簇セル 多数ノ脂肪顆䊀團 7 認ムルコト可ナリ多シ。大ナル壞死筐二於テハ，一般二脂 肪顆粒, 集簇二斯カル特殊ナル形状 7 認ムルコト能ハズシテ，唯病䇴ノ中央部

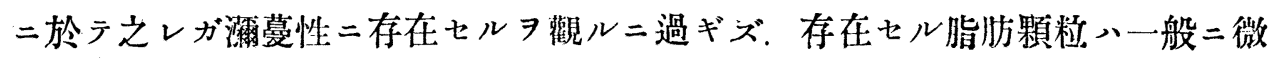
細ナルモ，又其融合シテ可ナリノ大サノ脂肪滴トナレルモノモアリ。

壇死䇴二多核白血球, 浸潤 7 認ムルコト屡イナリ。

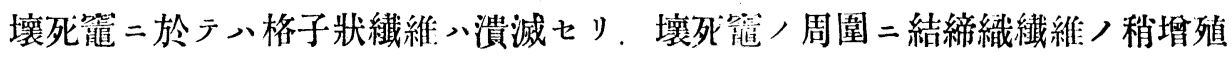
セル傾向ノ認メラル、モノ無キニ非ラザルモ，其結締織化セルモノハ認メラレ ズ. 又格子状纖維, 增殖モ殆ンド認メラレズ.

\section{6 細 胞・浸 潤}

上述，如ク壞死筐二白血球，浸潤习認ムルコトハ屡トナリ。サレド他ノ部位 
櫻窨吉进

(1181)

ニ於テ，細胞涥潤ノ認ムにキモノ無シ.

7 小葉間結締織部, 變化

門派枝及ビ肝動脈枝二充血. 7 認么。結締織性細胞ノ增加 $习$ 來シ，又胆管上皮 ノ稍增殖セル如キ觀 ヨ呈セルモノアレド，之八侹康家鬼二於テモ屡々認又得ル 所見ナレバくりさろびん中毒二因ル戀化ナリトシ覲シ.

\section{第 2 節 くりさろびん勆食二因ル肝臟變化}

1 血管撗張及ビ䒧盈.

邻食例二於テモ亦諸血管，擴張並二充血》観ル。然レドモ概シテ變化著シタ

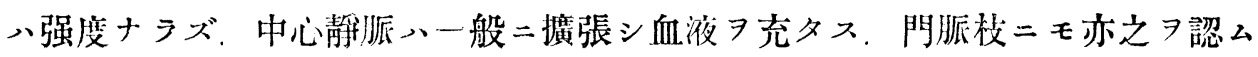
ルモ中心静派二比シテ輕度ナリ。肝動脈枝, 擴張七ルモ，殆ンド無シ。 小葉内 毛細血管ハ强ク擴張シテ充盈セルモノ茗シ。此毛細管充血八，或 、圭トシテ小 葉中心部二，又或八土トシテ小葉䧓邊部二著明ニシテ，其部位一定セズ，小葉

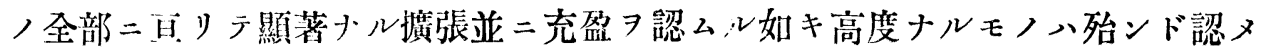
ラレズ.

血管内赤血球

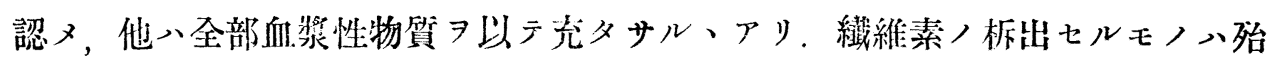
ンド認メラレズ，血管内 二血栓ヨ形成セルモノヨ觀ズ.

著明ナル血管援張二因リ，肝細胞，壓迫セラレテ，萎縮八狀ョ呈セル如キモ ノタ認メズ，後ニ記スル所アルガ如ク，却テ肝細胞ノ腫脹セルタ認メタリ.

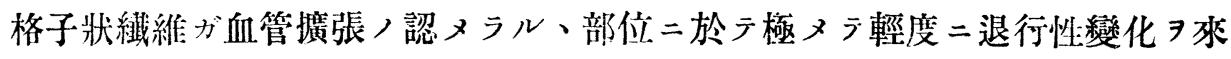
タセルヨ認メ得ルモノアリ。格子狀繊維が增㥀ヨ示セルモノハ殆ンド認メラレ ズ.

2 出 血.

邻食例二於テモ少數ナレド出血ノ認メラレタルモノアリ．而シテ其殆ンド全 部、毛細管出血ナリ.出血彗, 境界、明ラカナルモノアリ, 又稍濔募性ニシテ境 界ノ明䐲ナラザルモノアリ，其形ハ不規則ニシテー定セズ．大サ概シテホニシ テ，毛細血管ノ周圍二赤血球ノ多數二溢出七ル程度ノモノ多ク，一小葉ノ大部 
分或、全部二亘レルガ如キ大ナル出血 認ムルコト能ハズ. 出血筐二於デ,

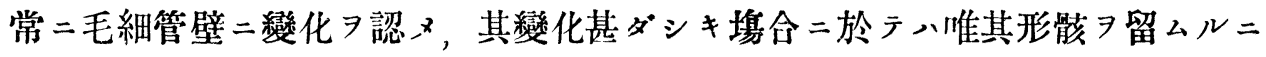
過ギザルョトアリ，又殆ンド之ヨ認メザルモノアリ。

出血䆠二於テ血色素ノ沈着七ルモノヨ認メズ.

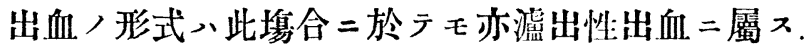

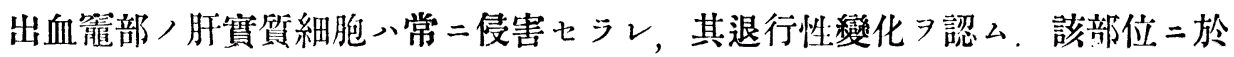

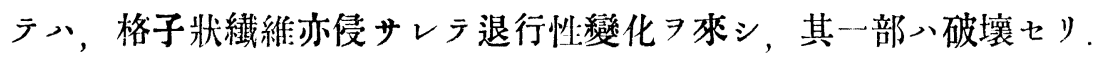

\section{: 溷 濁 腫 脹}

是亦能食試驗二於テモ認メラル。然レドモ一般二比較的輕度二シテ，著シク 高度ナルモノ八殆ンド認メラレズ，其比較的高度ナルモノ八，毛細血管ノ充盈 部二一致シテ認メラル, 從テ或ハ小葉, 中心部二, 或八其周僈部二認メラル. 此變化 7 呈セル肝細胞、腫脹シ容積大トナリ, 原形質メ一般二細顆粒狀 $コ$ 呈ス.

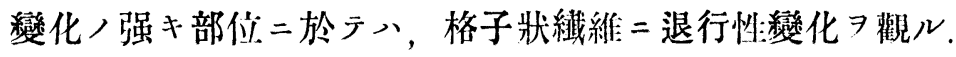

\section{4 脂 肪 變 性}

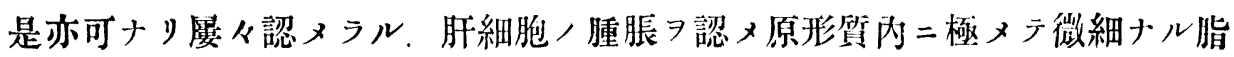
肪顆粒，存在七ル 見ル。脂肪顆粘，含有量ハ種々ニシテ，多數ナルアリ，又 少數ナルアリテー定セズ。サレド此塲合二於テモ亦細胞㷉二脂肪顆䉼 ル如キ高度ナルモノ無シ. 㤥、崩壞シくろまとりーぜ起セルモ八可ナリ多シ。 斯カル脂肪變性ガ小葉中心部二認メラル・コトアリ，又其周邊部二認メラル、 コトアリ、サレド小葉ノ全部或ハ大部分ニ旦レルガ如キモノハ認メラレズ，脂

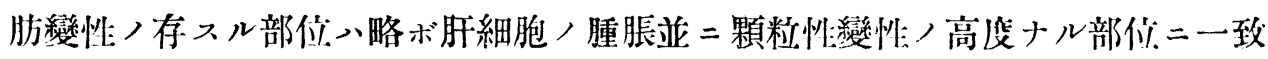
ス.

上述八如》此璌合二於テモ，細胞內二出現スル脂肪顆粒八常二微細ニシテ， 可ナリノ大サヨ有スル脂肪滴ノ認メラル、コトナシ。 又脂肪顆粘y刨含スル細 胞ノ健常ナルモノ無ク, 常二其退行性變化 $コ$ 起七ルヨ認ム。即于脂肪浸潤卜稳 ス可キ像ヨ顀ザルナリ。

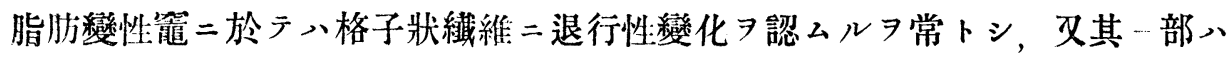
崩壤消失七リ。 
概并吉述

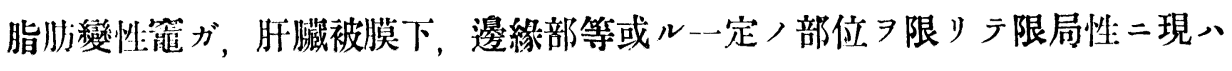
ル、ガ如キ事實無シ.

5 壤死

壞死モ亦可ナリ膺々認メラル，大サハ種々ナレド，多クハ一小葉內ノ一局部 ニノミ來リ，一小葉ノ大部分又心全部二亘ル如キ大ナルモノ少シ。多數ノ小葉 ガ壤死二陷レル如キ大ナルモノ無シ.

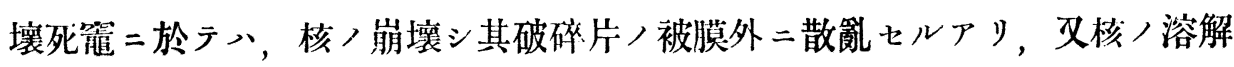
ヨ起七ルモノアリ。核ノびくもーせ二陷レルモノ少ク, 腔胞

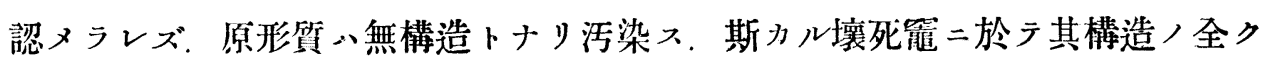
不明トナレルモノアリ，又少ホ細胞ノ形能殘セルモノアリ．又全ク壞死二陷 ラザルモ將二壞死セントセルモノモ認メラレタリ.

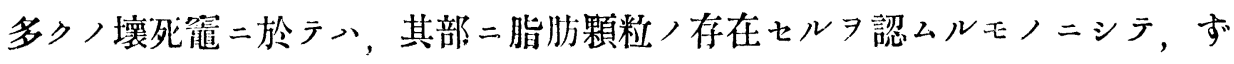

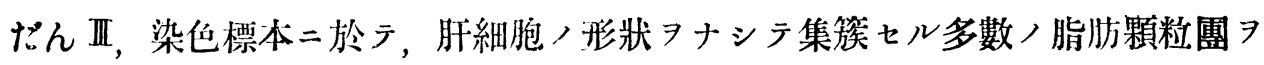
認ムルコト可ナリ多シ。然レドモ秒大ナル壤死筐ニアリテハ，一般二脂肪顆粘

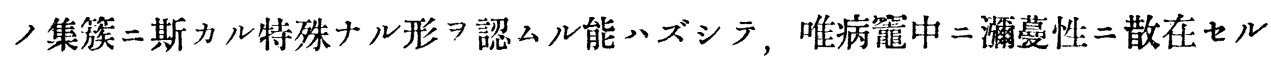
ヨ認ムルニ過ギザルモノアリ，存在七ル脂肪顆棹、一般二微細ナルモ，又其融 合シテ可ナリノ大サノ脂肪滴トナレルモノモ認メラル.

壤死筐二多核白血球, 浸潤ヨ認ムルモノアリ.

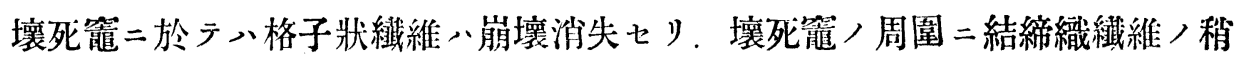
塯加セル觀アルモノ無キニ非ラザルモ，其結締織化セルモノハ認メラレズ，又 格子狀繊維ノ增殖モ殆ンド認メラレズ.

\section{6 細 胞 漫 潤}

壞死鼅二白血球, 浸潤ヨ認ムルコトアルハ, 既二記述シタリ。然レドモ他ノ 部位ニ於テ細胞浸潤ノ認ムべキモノ無シ.

\section{7 小葉結締織部ノ變化}

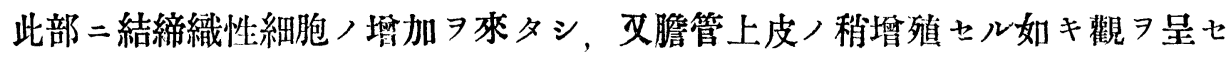


ルモノアレド，之、健康家鬼二モ屢々認メラル、所見ニシテ，くりさろびんニ 因り惹起セラレタル變化ナリトシ難シ.

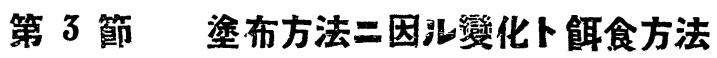 二因ル變化トノ比較}

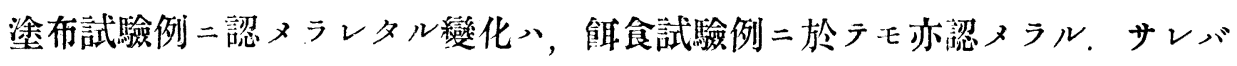
敦レカニ特殊ガル變化ト稱スぶキモノ無シ。蓋シ腎臟變化 7 報告シタル際盶二

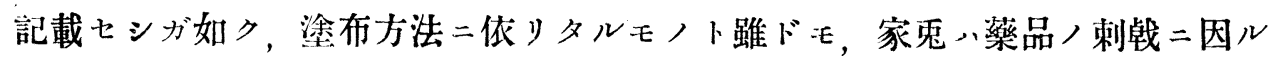

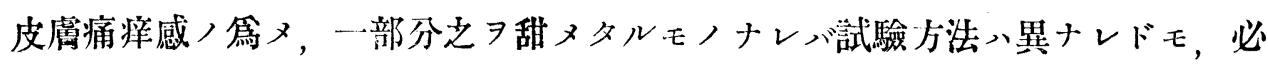
竟真二異ナレル點ハ吸收量ノ多賽二過ギザルコト，此事實二關係アルャモ测リ 難シ。今認メラレタル諸種ノ變化ノ程度二就テ, 其各ゃ 7 比較スハシシ.

血管撗張及ビ充盈八，塗布試驗二於ヶルナガ强シ.

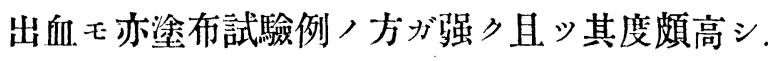

溷濁腫脹及ビ脂肪浸潤モ塗布試驗例ノ方稍强度ナリ。サレド其頻度ハ何レノ 方法ニ因ルモ大ナル差異习認メズ.

壤死入其大サニ於テモ，塗布試驗例，方ニ大ナルモノタ認メタルガ，其現、 ル、頻度二於テモ, 㮃布試驗例ノ方高シ.

著明ナル細胞浸潤八敦レモ認メラレズ.

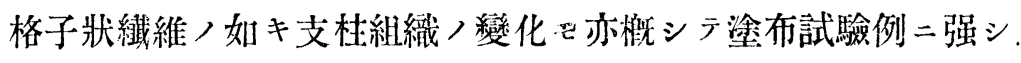

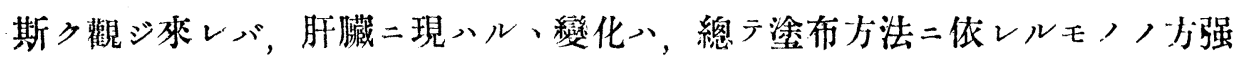
シ. 是くらさろびん二因り㘃起セラル、變化ハ圭トシテ退行性變化ニシテ進行 性變化ナク，而シテ塗布試驗例二於テノ，䬺食試驗例二比シ著シク多量〉くり さろひんガ吸收セラレ，急性ノ經過 ヨ取ルニ由ルモノナルぶシ.

\section{第 3 章 くりさろびんニ因ル肝臟筫化}

\section{二對スル考察}

塗布或、飭食/方法二依り，〈りさろびんガ體内二吸收セラレテ肝臟二達ス ルャ，其毒作用二因リ，先ヅ諸血管系二充血 $尹$ 隶シ，其毒作用ノ激甚ナル晧合 
櫻喜吉迅

ニ於テハ, 少ホ血管壁

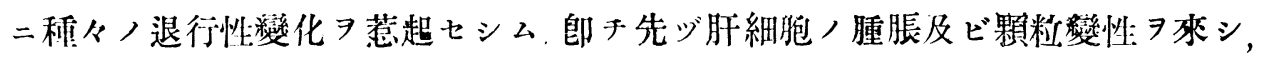

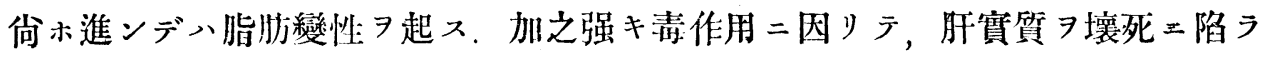
シム，格子狀㵶維モ亦共二傷害セラレテ，溉行性變化ヨ起ス，斯カル種々ノ變 化ハ, 吸收七ラル、くりさんびん, 量二應シテンノ程度二差異アリテ, 非常二 多量二吸收セラル、特八變化亦甚ダ强シ，然ラバ是等/諸變化ハ，くりさろひ ん中毒二於ヶル特殊八變化ナリヤ否ヤ，或ハ又斯カル變化カ如何ナル疾患二於 テ認メラル、コトアリャ等二就キテ考案シ, 其大要 7 記述スベシ.

溷濁腫脹ガ諸種，急性傅染病或、中毒等二於ラ認メラル、コト既二周知ノ事 實ナリ。サレバ之ガくりさろびん二因ル特殊㱍化ナリトスルニ非ラザルセ，夫 レニ依リテ惹起セラレタル戀化ナルコトハ明ラカナリ。

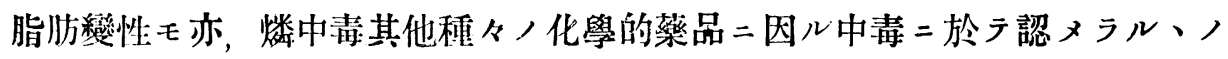
ミナラズ，又諸種ノ傳染州矤患二於テ之ヨ觀ルコト既定ノ事實ニシテ，成書或

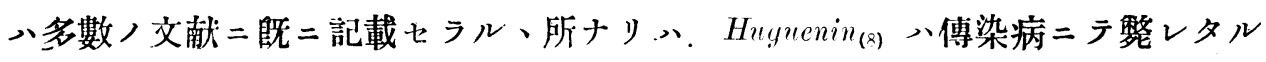
人體及ビ動物ノ肝臟二於テ，麻《限局性ノ脂肪化層

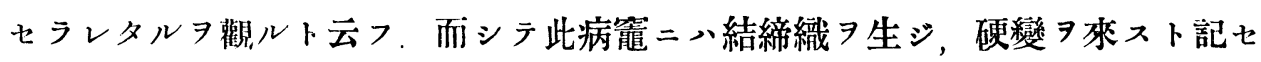
リ，余ノ鹪合二於テハ, 結締織 又同氏八同著二於テ，健康ナル動物ノ健康ナル肝臟二於テモ，被膜下或八邊緣 部等或ル一定ノ部位二, 限局性ノ脂肪籃ヨ認ムルコトアリト云フ。然レドモ此 㙫合ニハ肝細胞，甥害セラル、コトナシト琚載セリ、余，實驗例二於テハ，脂 肪化筐ニテハ, 常二肝細胞二退行性變化习認メタレバ夫レニハ該當セズ.サレ バ此脂肪變性ガくりさんびん中毒ノミ認メラル、モノニハ非ラザルモ，之八溷 濁腫脹, 强キ部价: 認メラレタルコトハ既二記述シタルガ如クニシラ，夫レョ リ移行セルモノナルコト明ラカナルノミナラズ,〈りさろひんん因り惹起七ラ レタルモノナルコト柴トスルノ要ナシ.

塆死モ亦諸種ノ疾患二於テ認メラル。腸空扶斯ノ際二之ヨ發現スルハ周知ノ 
(1186)

くりさろびん中毒二因ル家兔䏦臟ノ變化二就テ

事實ニシテ，其發生原因二關シテモ種々論議セラル、所アリ。郎チ Juffe $e_{(9)}$

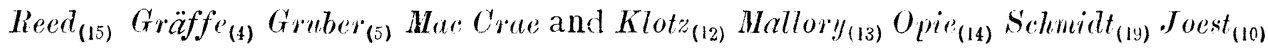
等 始メ多數ノ學者二依リテ論ゼラレ或、脾細胞栓塞說 子樣血栓形成二由ルト第シ，或ハ主トシテ菌體自己二由來メトナシ，又或ハ菌 毒素ニ因ルトナセリ，而シテ我教室ノ佐川(17) モ腸窒扶斯症其他ノ急性疾患二之

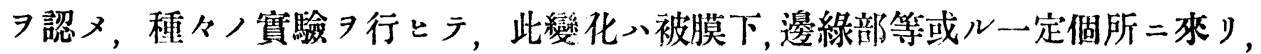
毒作用ノ他，器械的作用ノ之二關與スルモノナルタ說ケリ。而シテ此限局性壞

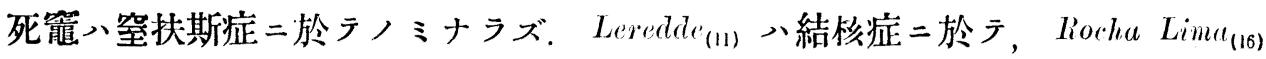
八麻疹二於テ, Freemann(3) 八猖紅熱二於テ, Hildebrund ${ }_{(6)}$ 八且性天然痘二於テ，又 Weigert ${ }_{(20)}$ 横尾(21) 等八

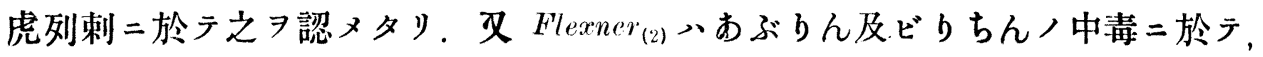
實驗的二之ヨ認メタリ。星島(7) 八特殊慨食二因リ肝臟二之 條(18) 八百髪染（主成分ぱらふえにーるぢあみえ）习用ヒテ實驗的二之ヨ認メタ リ。其他多數ノ學者二依リテ，或八黄熱病二，或八昇录中毒二，或八日本住血 吸蛅病, 肝牁

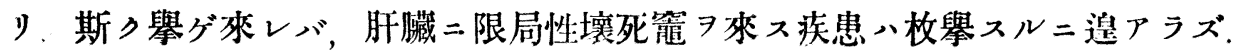
サレバ余ノ實羷例ニ於テ認メタルモ。夫レヨくりさろひん特有ノ變化ナリト謂 フニ非ラズ. 然レドモ之ガ本中毒二因り惹起七ラレタルモノナルコトハ否定ス

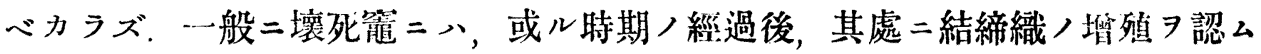
ルョ常トスルモ, 余ノ例ニテハ斯カルモノ二遭湡セザリキ，是レ余ノ㰾合二於 テハ，整死スルカ或ハ屠殺スル迄くりさろびんノ使用 係アルモノナルぶシ。然レドモ第29號動物ノ如キモノニ於テモ，壞死䇫二之 認メザリシコト泩目二值ス可シ.

之ヨ要スルニ, 余ノ實驗例二於ラ認メラレタル諸變化》其程度ノ差違》除外 スレバ,くりさろびん中瑇ニノミ認メラル、如キ特殊ノモノ無ク, 唯諸種, 化 學的薬品二因ル中毒症二於ラモ觀ラル、モノノ認メラル、ニ過キズ. 
橮喜吉述

(1187)

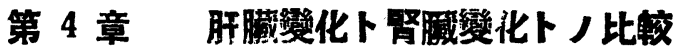

くりさろびん中毒二於テ, 肝臟卜腎蔵トノ間二如何ナル變化ノ差違 ヨ來スカ, 又同一病變ニアリテハ其程度二如何ナル差違アリャ等ニ就キテ，比較考察スべ シ.

既二報告セルガ如ク，腎臟二於テハ絲氆體二岑性變化 7 認メ，間質二モ亦細 胞浸潤 ニシテ，他ノ部位ニ八細胞浸潤ト稳スべキモノタ認ムルコト能ハズ.

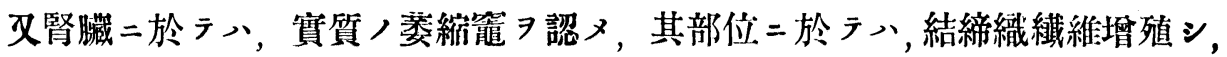
格子狀纎維モ亦檑殖セルョ觀タルガ, 肝臟ニ於テハ斯カル所見 リキ。

血管撗張及ビ充盈ハ兩者ノ間二大ナル程度ノ差異 認ムル能ハズ，出血心腎 臟二於テモ肝臟二於テモ之ヨ認メタルガ，肝臟ノ方ガ其頻度高シ。血色素ノ沈 着八腎贜ニ於テハ之ヨ認メタルモ，肝臟ニ於テハ之

溷滥腫脹入，腎藏ニ於ヶル方ガ，高度ノモノ多シ。

脂肪變性一肝臟二於テッ屡々認メラレタルモ，腎臟ニ於テハ之ヨ認メ得ザリ キ.

壤死閿、腎藏ニ於テモ觀ラレ得レド，肝臟ノ如ク强度ナルモノ無シ。其部二 於ヶル石灰沈着ハ腎臟ニノミ認メラレ，肝藏ニ於テハ，壤死筐ノミナラズ，血 管壁ニモ之ヨ認メザリキ。

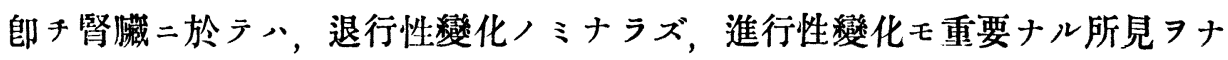

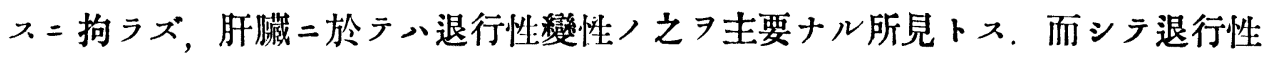

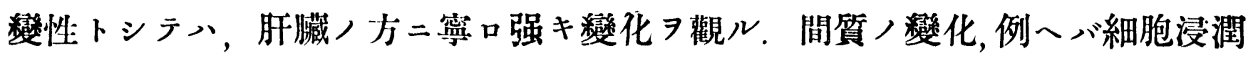
結締織增殖等八腎藏ニノミ認メラル，斯カル所見ノ相違入, 勿論器官ノ相違二 由隶スルモノニシテ, 腎藏二於テン, 肝臟二比シラ進行性變化起リ易タ, 脂肪

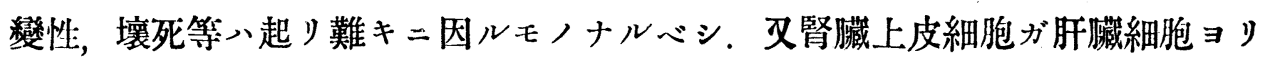
モ再生セラレ易キコトハ，獨り本中毒ノミナラズ諸種病變ニモ認メラルル所ナ リ. 


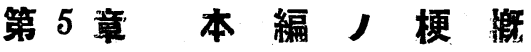

くりさろびん中毒症ニ於ヶル肝臟ノ變化二就ティ，其業績ノ未ダ世二公二七

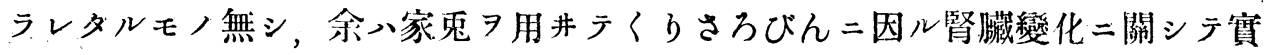

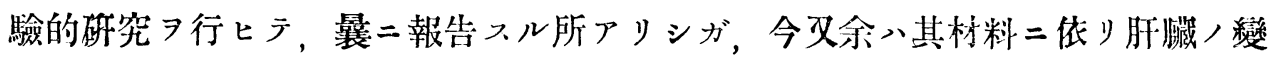
化习檢索シ，其詳細、既二各章二亘りテ記載シタリ。

茲二其梗概习略記スレバ次ノ如シ

(1) 肝臟變化, 强弱 、，1回二使用スルくりさろびんノ量二由リテ異ナル， 換言スレバ吸收セラル、くりさろびんノ量多キモノ程，變化强シ。

（2）此故二塗布方法二因りタルE，、方，領食試驗例二比シ，總テ，變化强 シ.

（3）くりさろびん二因リ惹起セラル、主要ナル肝㵴變化入，血管ノ充盈，出 血，泪濁腫脹，脂袣變性，限局性壞死等ナリ。

（4）是等ノ諸變化八，小葉中心部二桃ルコトアリ，又其周圍部二來ルコトア リテ，其部估一定七ズ，變化强キ特ハ小葉，全部二亘リラ變化ヨ認ム。

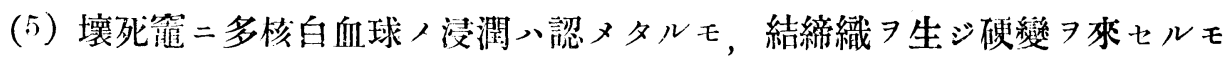
久ヌ觀ズ.

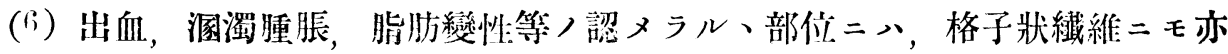

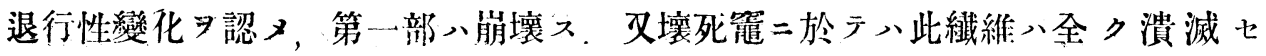
皮.

（7）小葉間結締織部ニハ著明ナル變化認メラレズ.

終り二臨ミ恩師藤浪数授並二清野呚授, 御筤篤ナル御指導 7 深ク感謝シ且ッ 小林講師ガ援助ト便宜: 與へラレタルヨ敬謝ス。

\section{主要ナル參考文献}

1) Councilmann, Mallory and Pearce, Diphtheria. Boston. 1901.

Flexner, The Journal of experiment. medicine. 1897. of the dep. of path. Columb. Univ. Bd. 7, 1899/1900. Archiv, f. klin. Med. 125, 1918. u. 126, 1918. u. Parasitenk. 77, 1916.

6) Hildedrand, Münch. med. wochenschr. 48, 1910.
3) Freemann, Study

4) Gräffe, Deutsch.
7) 星島, 京都醫學雜誌, 第18卷, 第11號. u. Path. Anat. Bd. 36, Nr. 2/3, 1925.
8) Huguenin, Centralbl. f. allg. Path.

9) Jaffe, Virchow's Archiv. Bd. 228, 1920. 
10) Joest, Verh. d. deutsch. Peth. Gesellschaft. 17, 1914.

11) Leredde, I,e

Progres médical. 25, 1894.

bact. Pd. 12, 1908,

1908

14)

Opie, Journal of med. research. No. 12, 1904.

The Amer. journ. of the med. sciences. Nov. 1895.

16) Rocha Lima, Verh.

c. deutsch. path. Gesellschaft. 15, 1912.

17）佐川，日本海理學會會誌，第16年.

18）西條，日本微生物罗!會雜誌，第21卷、第 5 號。

19) Schmidt, Centralbl. f.

allg. Path.u. Path Anat. 18, 1903, Verh. d. deatsch. path. Gesellschaft. 17, 1914.

20 ,

Weigert, Berl. klin. Wochenschr. 1874.

21）橫尾，日本病理學會會誌，第16年， 


\section{附 圖 锐 明}

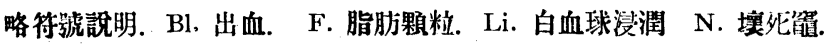

第1圆 へまききしりんえおじん複染色標本.

擴大. Zeiss. 接眼鏡 HI. 接物鏡あぼくろまーき10. 隌箱 $35 \mathrm{~cm}$. 小葉內毛細管〉出血 示入.

第2圖 へまききしりん、えおじん複染色標本.

撗大. Zeiss. 接眼鏡 K4. 接物鏡あぽくろまーき 10 . 暗箱 $60 \mathrm{~cm}$.

第3 圖 へまききしりん.えまじん複染色標本.

擴大. Zeiss 接眼鏡 HI. 接物鏡 あぼくろまーき 10 . 暗箱 $50 \mathrm{~cm}$.

壊死筩二於ケル多核白血球ノ浸淍キ示ス。

第 4 圖すだん III，染色標本

擴大.Zeiss. 接眼鏡 HI. 接物鏡あぽくろまーき10. 暗箱 $35 \mathrm{~cm}$.

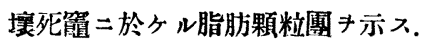




\section{第一圖}

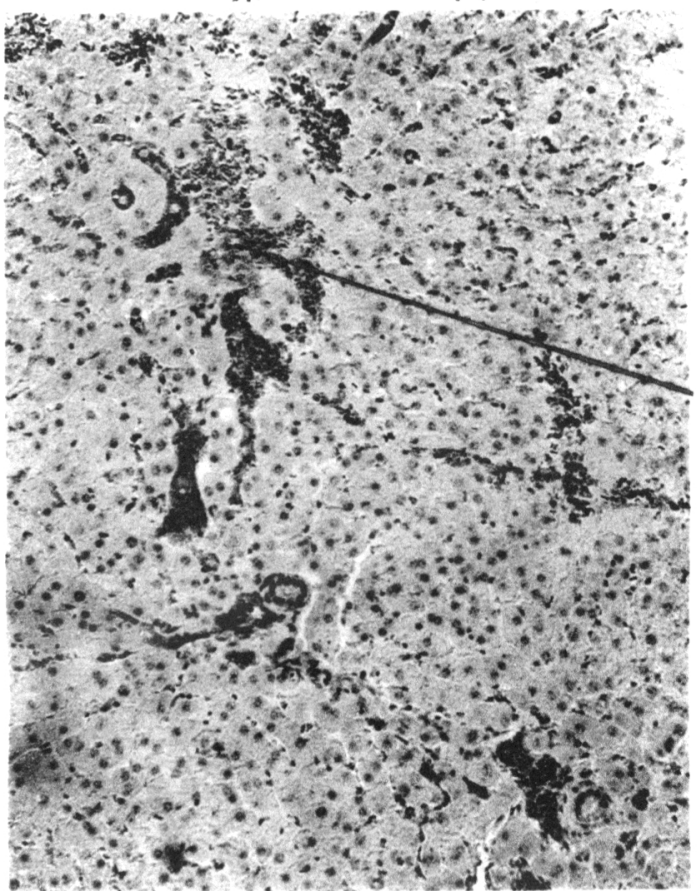

符 三圖

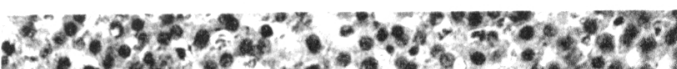

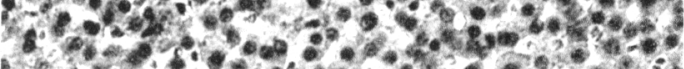

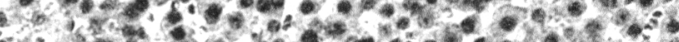

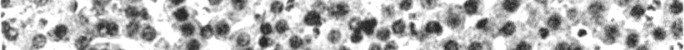

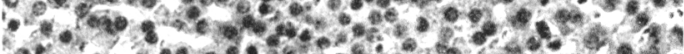

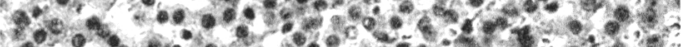

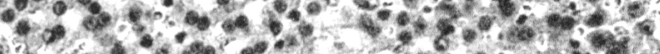

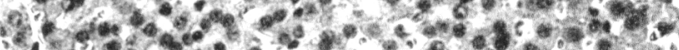

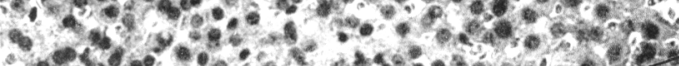

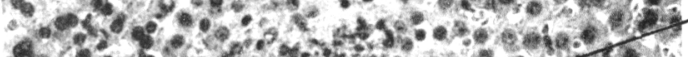

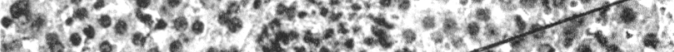

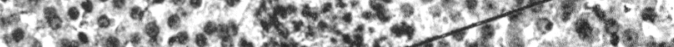

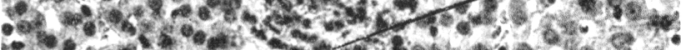

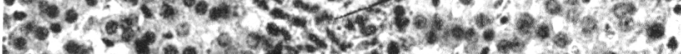

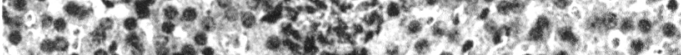

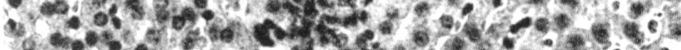

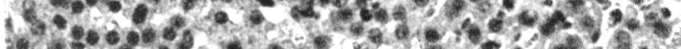

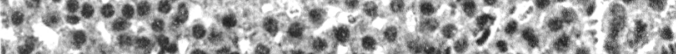

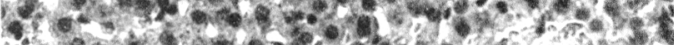

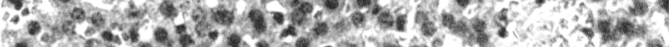

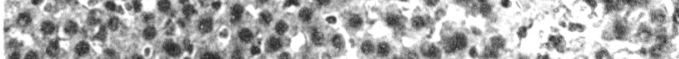

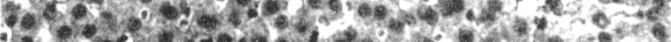

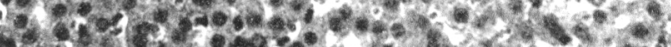

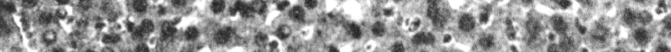

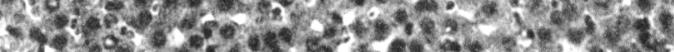

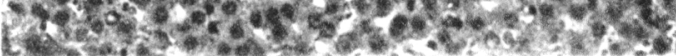

第 二 圖

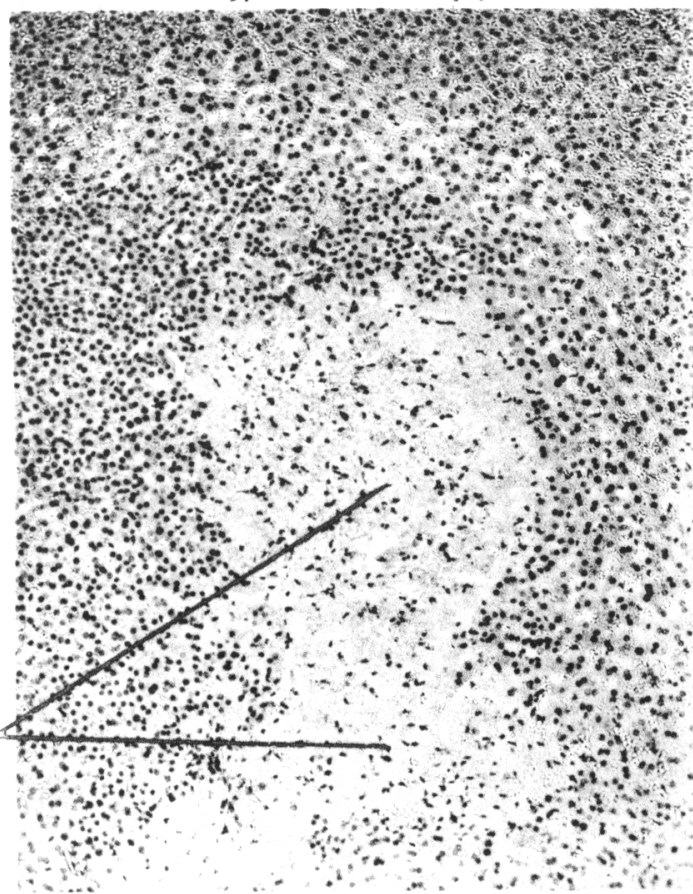

第四圖

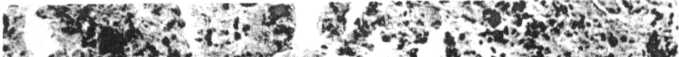

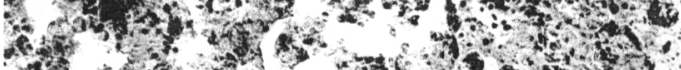

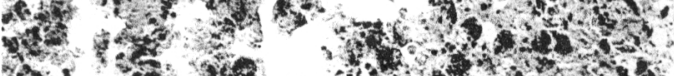
H.

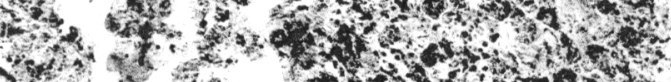

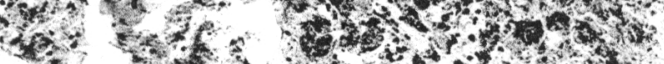

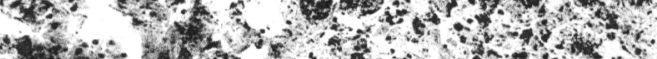

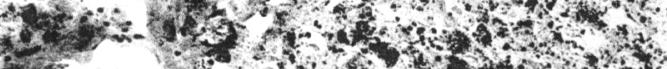

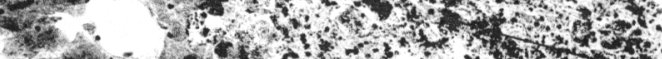

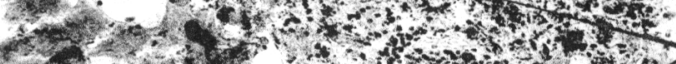

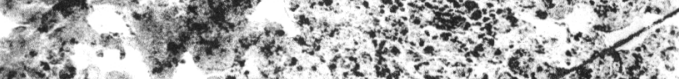
8.0.

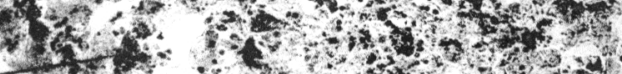

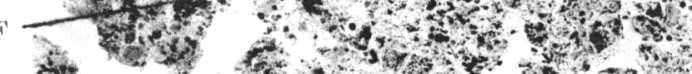

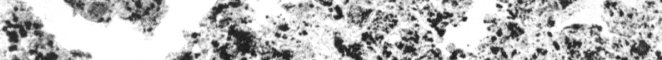

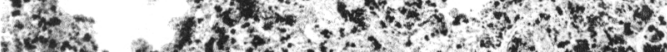

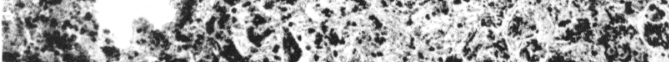

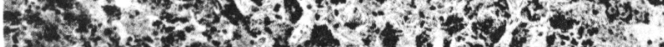

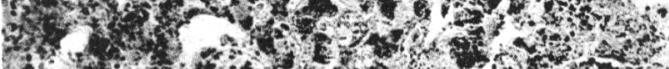

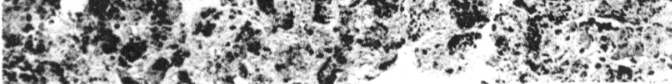

